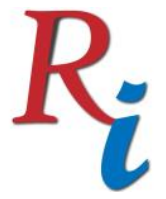

Asia Proceedings of Social Sciences

(APSS)

www.readersinsight.net/APSS

\title{
CRiticAl PRAGMATIC ANALYSIS OF ARGUMENT OF THE FIRST-ROUND PRESIDENTIAL DEBATE
}

\section{Yuliana Setyaningsih ${ }^{\star}$}

Master Program of Indonesian Language and Literature Education Sanata Dharma University, Yogyakarta Indonesia

\section{R. Kunjana Rahardi}

Master Program of Indonesian Language and Literature Education Sanata Dharma University, Yogyakarta Indonesia

*Corresponding author’s Email: yulia@usd.ac.id

Author's Biography

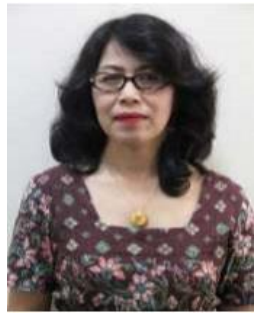

Dr. Yuliana Setyaningsih, M.Pd., was born in Yogyakarta, Indonesia, on October 1, 1963. She serves as a senior lecturer at the Master Program in Indonesian Language and Literature Education, Sanata Dharma University, Yogyakarta. She graduated from the Doctorate Program of Indonesian Education University, Bandung, in the field of language teaching and education in 2008.

Peer-review under responsibility of $3^{\text {rd }}$ Asia International Multidisciplanry Conference 2019 editorial board (http://www.utm.my/asia/our-team/) () 2019 Published by Readers Insight Publisher, lat 306 Savoy Residencia, Block 3 F11/1,44000 Islamabad. Pakistan, info@ readersinsight.net This is an open access article under the CC BY-NC-ND license (http://creativecommons.org/licenses/by-nc-nd/4.0/). 


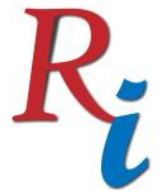

Asia Proceedings of Social Sciences

(APSS)

www.readersinsight.net/APSS

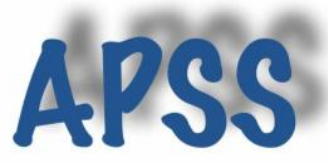

\section{Rese a r ch H i g h I g h t s}

The results showed that there are simple patterns of argument containing claim, subclaim, data, and warrant (Kneuper, 1978). The orders of elements of arguments might be varied. The research results also showed that there were various pragmatic meanings found in the arguments used by the president and vice-president candidates (Palacio \& Gustilo, 2016). The results of the study which was analyzed using the critical pragmatic perspective reflect how far the candidates were concerned with the marginalized, the underprivileged, and the subjugated people.

\section{Research Objectives}

The objective of this research is to investigate the depth and breadth of the arguments stated by the presidential candidates and how those arguments are presented (Wodak, 2007). It is important for politicians to have a good argumentative skill. For state leaders, the ability to think logically, to use rhetoric, and to argue systematically, scientifically, sharply, and eloquently is very crucial. The year 2019 is the political year for Indonesia. Political campaigns leading to the presidential and the legislative election, both in national and regional levels, will happen in 2019.

\section{Methodology}

The substantive data sources of this research is the recorded video of the first-round presidential debate dated January 17, 2019. The recorded video consists of six segments discussing a range of topics such as Law, Human Rights, Corruption, and Terrorism. The research data is the excerpts of utterances containing argumentative elements proposed by Toulmin (Harper, 2011). The data was gathered using the observation method by employing recording and note-taking techniques as the basic and advanced techniques (Rahardi, 2016; Mahsun, 2005). The research data will be further analyzed using Toulmin's theory of argument and the critical pragmatic theory and contexts. Therefore, the analysis method to be used to analyse the research data was the the distributional and contextual analysis methods (Sudaryanto, 2016).

\section{Results and Findings}

The results showed that there are simple patterns of argument containing claim, subclaim, data, and warrant (Ray, 2004). The research results also showed that there were various pragmatic meanings found in the arguments used by the president and vice-president candidates. The results of the study which was analyzed using the critical pragmatic perspective reflect how far the candidates were concerned with the marginalized, the underprivileged, and the subjugated people. The claim, the support, and the warrant are presented clearly and prove that they have a high degree of directness. The high degree of directness is actually not ideal to convey certain intentions which contain facts (Schandorf, 2013). However, seen from the speaker's intention, the presidential candidate tries to convince that the leader of the country must be a person with good reputation. His supporters must also be clean, without criminal records, corruption allegations, etc. Most of the data shows that the major parts of Toulmin's argument, i.e. the claim, the support, and the warrant, are fulfilled in the presidential candidates' arguments (Setyaningsih, 2013); . Furthermore, from the critical pragmatic perspective, it can be confirmed that the presidential candidates and their running mates have great concern and care for the marginalized, 


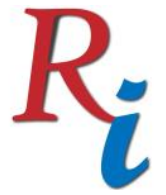

\section{Asia Proceedings of Social Sciences (APSS) \\ www.readersinsight.net/APSS}

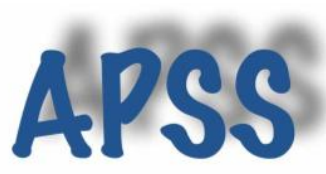

disadavantaged, and neglected people in the society and nationhood. Their dictions indicate that each of the president candidates take sides with the economically, socially, politically disadvantaged people. The structure of an argument presented by the presidential candidates and their running mates in the first-round presidential debate is clear and simple. Data shows that most of the arguments start from the positional statement (the claim) which is followed by supports and warrant. Some analyzed data also shows that the presidential candidates start their arguments by presenting data first before following it with positional statement (the claim) and the warrant (Kneuper, 1978). The sub-claim is raised by the presidential candidates in the debate when they feel that the claim they have made needs more elaboration to gain stronger effect.

\section{Acknowledgement}

This research is supported by DRPM, Ministry of Research, Technology, and Higher Education, Republic of Indonesia. The writers thank the continual supports given for more than six years.

\section{References}

Harper, D. (2011). Choosing a Qualitative Research Method. In Qualitative Research Methods in Mental Health and Psychotherapy: A Guide for Students and Practitioners. https://doi.org/10.1002/9781119973249.ch7

Kneuper, C. W. (1978). Teaching Argument: An Introduction to the Toulmin Model. College Composition and Communication. https://doi.org/10.2307/356935

Mahsun, M. (2005). Metode Penelitian Bahasa. Jakarta: PT Raja Grafindo Persada. https://doi.org/10.1200/JCO.2008.17.1991

Palacio, M. A., \& Gustilo, L. (2016). A pragmatic analysis of discourse particles in Filipino computer mediated communication. GEMA Online Journal of Language Studies, 16(3), 1-19. https://doi.org/10.17576/gema-2016-1603-01

Rahardi, K. (2016). Personal and Communal Assumptions to Determine Pragmatic Meanings of Phatic Functions. Lingua Cultura, 10(2), 95. https://doi.org/10.21512/lc.v10i2.897

Ray, L. (2004). Pragmatism and Critical Theory. European Journal of Social Theory. https://doi.org/10.1177/1368431004044195

Schandorf, M. (2013). Mediated gesture: Paralinguistic communication and phatic text. In Convergence. https://doi.org/10.1177/1354856512439501

Sudaryanto. (2016). Metode dan Aneka Teknik Analisis Bahasa (1st ed.). Yogyakarta: Sanata Dharma University Press.

Wodak, R. (2007). Pragmatics and Critical Discourse Analysis. Pragmatics \& Cognition. https://doi.org/10.1177/0957926593004002006

Setyaningsih, Y. (2013). Metakognisi sebagai Keterampilan Melatih Siswa Berpikir Kritis dalam Pembelajaran Bahasa. In Yuliana Setyaningsih dan R. Kunjana Rahardi (Ed.), Prosiding Seminar Nasional PBSI, FKIP, Universitas Sanata Dharma (p. 166). Yogyakarta: Universitas Sanata Dharma. 